\title{
EFFECTS OF H. PYLORI ERADICATION ON METABOLISM AND BODY WEIGHT IN OBESE AND NON OBESE PATIENTS.
}

Roca-Rodríguez $\mathrm{MM}^{1}$, Cornejo-Pareja I ${ }^{1}$, Coín-Aragüez L², Alcaide-Torres J², Clu-

Fernández $\mathrm{C}^{1}$, Durán-Martín $\mathrm{E}^{3}$, Mora-Navas $\mathrm{L}^{3}$, Gómez Pérez $\mathrm{AM}^{1}{ }^{1}$, Molina-Vega $\mathrm{M}^{1}$,

Díaz-Perdigones $\mathrm{C}^{1}$, Mancha-Doblas $\mathrm{I}^{1}$, Tinahones $\mathrm{FJ}^{1,2}$.

1 Department of Endocrinology and Nutrition. 2 Investigation Unit (IBIMA). 3 Department of Microbiology. Virgen de la

Victoria Hospital, Malaga, Spain.

\section{BACKGROUND}

Many studies showed that $\mathrm{H}$. pylori infection could be an independent predictor for insulinresistance and could regulate metabolism and body weight.

\section{AIM}

To evaluate changes in metabolism induced by an oral glucose tolerance test (OGTT) before and after antibiotic eradication treatment in patients colonized by H. pylori.

\section{MATERIAL AND METHOD}

Prospective case-controlled study with a sample of patients colonized by H. pylori. In an intra-subject analysis, clinical data and levels of ghrelin and GLP1 were analyzed at baseline and post-OGTT before and after antibiotic eradication treatment.

\section{RESULTS}

* We studied 32 patients (75\% women). Average age was $49 \pm 11.5$ and 46.9\% had personal history of gastrointestinal disease.

* We found a significant decrease of HbA1c and 120 Post OGTT glucose after treatment.

* Significant correlations between ghrelin with waist circunference and BMI (negative), and with glucose, insulin, HbA1c and LDL-Chol (positive). We also found significant positive correlations between GLP1 and insulin, and between the difference in HbA1c and levels of GLP-1 post-treatment at all times after OGTT.

* The prevalence of obesity (defined as $\mathrm{BMI} \geq 30$ ) at baseline was $21.9 \%$ $(\mathrm{n}=7)$

$\checkmark$ No significant differences were found in obese patients before and after treatment, whereas non-obese patients showed significant decrease in levels of 120 Post-OGTT glucose ( $6.24 \pm 0.44$ vs. $5.53 \pm 0.43 \mathrm{mmol} / \mathrm{L}, \mathrm{p}=0.032)$ and $\mathrm{HbA1c}(5.5 \pm 0.1$ vs. $5.3 \pm 0.07 \%, \mathrm{p}=0.038)$, both with successful $\mathrm{H}$. pylori eradication.

$\checkmark$ Comparing the results before and after eradication therapy between nonobese and obese patients with successful $\mathrm{H}$. pylori eradication, we found some significant differences pre-treatment such as fasting insulin (46.6 \pm 6.5 vs. $116.2 \pm 28.7 \mathrm{pmol} / \mathrm{L}, \mathrm{p}=0.001)$ and C-peptide ( $2.2 \pm 0.1 \mathrm{vs.} 3.1 \pm 0.5$ $\mathrm{mcg} / \mathrm{L}, \mathrm{p}=0.007)$; and fasting insulin post-treatment (49.5 \pm 4.3 vs. $105.5 \pm$ $43.8 \mathrm{pmol} / \mathrm{L}, \mathrm{p}=0.020$ ).

* $78.1 \%$ of patients completed correctly the treatment and $81.3 \%$ achieved the eradication of $\mathrm{H}$. pylori.
Table 1: Clinical and analytical variables pre- and post-treatment.

\begin{tabular}{|l|c|c|c|} 
& $\begin{array}{c}\text { Pre-treatment } \\
\text { visit }\end{array}$ & $\begin{array}{c}\text { Post-treatment } \\
\text { visit }\end{array}$ & P \\
\hline Weight (Kg) & $71.9 \pm 2.2$ & $71.6 \pm 2.4$ & 0.509 \\
\hline BMI & $27.1 \pm 0.8$ & $27.1 \pm 0.9$ & 0.861 \\
\hline WC (cm) & $91.4 \pm 2.1$ & $90.7 \pm 2.3$ & 0.520 \\
\hline HC (cm) & $102.7 \pm 1.5$ & $104.8 \pm 2.0$ & 0.127 \\
\hline SBP (mmHg) & $124.2 \pm 3.0$ & $121.8 \pm 4.1$ & 0.457 \\
\hline DBP (mmHg) & $77.9 \pm 1.6$ & $79.9 \pm 2.1$ & 0.283 \\
\hline Creatinine (mmol/L) & $61.88 \pm 2.65$ & $61.88 \pm 1.77$ & 0.192 \\
\hline TG (mmol/L) & $1.12 \pm 0.09$ & $1.06 \pm 0.08$ & 0.485 \\
\hline TotaL-Chol (mmol/L) & $5.16 \pm 0.20$ & $5.01 \pm 0.17$ & 0.601 \\
\hline HDL-Chol (mmol/L) & $1.22 \pm 0.06$ & $1.25 \pm 0.07$ & 0.084 \\
\hline LDL-Chol (mmol/L) & $3.20 \pm 0.18$ & $3.09 \pm 0.17$ & 0.606 \\
\hline GOT (UI/L) & $20.2 \pm 1.6$ & $22.2 \pm 2.1$ & 0.309 \\
\hline GPT (UI/L) & $26.7 \pm 2.0$ & $28.1 \pm 2.4$ & 0.626 \\
\hline GGT (Ul/L) & $27.7 \pm 5.1$ & $24.3 \pm 3.5$ & 1.000 \\
\hline CRP (mg/L) & $3.9 \pm 0.4$ & $3.7 \pm 0.5$ & 0.943 \\
\hline IGF1 (kU/L) & $162.1 \pm 12.7$ & $157.9 \pm 12.5$ & 0.250 \\
\hline GH (mcg/L) & $1.7 \pm 0.3$ & $1.3 \pm 0.2$ & 0.178 \\
\hline C-peptide (mcg/L) & $2.4 \pm 0.1$ & $2.4 \pm 0.15$ & 0.819 \\
\hline HbA1c (\%) & $5.5 \pm 0.09$ & $5.4 \pm 0.1$ & $0.035^{*}$ \\
\hline HbA1c (mmol/mol) & $37 \pm 0.56$ & $36 \pm 0.62$ & \\
\hline & & &
\end{tabular}

\section{CONCLUSIONS}

Significant improvement in carbohydrate metabolism was observed after $\mathrm{H}$. pylori eradication. No significant differences in body composition, blood pressure figures and levels of ghrelin and GLP-1 were found after treatment, but nearly-significant decline in ghrelina. Significant correlations between plasma glucose and insulin with ghrelin and GLP-1 were found. More than $85 \%$ of patients achieve H.pylori eradication. 